\title{
Lingual Cystadenoma: Rar Location and Rare Cause of Odynophagia in Adults
}

\author{
Belhaj Najoua $^{1,3 *}$, N. Benkhraba ${ }^{1}$, I. Boumendil ${ }^{1}$, S. Nitassi ${ }^{2}$, A. Oujilal $^{2}$, R. Bencheikh ${ }^{2}$, M.A.Benbouzid ${ }^{2}$, L. Essakalli $^{2}$
}

${ }^{1}$ Resident Physician in Otorhinolaryngology, Department of Otorhinolaryngology, Head and Neck Surgery, Ibn Sina University Hospital, Rabat, Morocco

${ }^{2}$ Professor of Otorhinolaryngology, Department of Otorhinolaryngology, Head and Neck Surgery, Ibn Sina University Hospital, Rabat, Morocco

${ }^{3}$ Faculty of Medicine and Pharmacy of Rabat, Mohammed V University, Rabat, Morocco

DOI: $\underline{10.36347 / \text { sjmcr.2020.v08i11.005 }}$

| Received: 13.08.2020 | Accepted: 21.08.2020 | Published: 11.11.2020

*Corresponding author: Belhaj Najoua

Abstract

Case Report

Salivary gland tumours (SGT) represent an important chapter of facial cervico pathology. Salivary gland tumours are rare and very varied. Cystadenoma is a rare epithelial tumour of the salivary glands (WHO 2005). It preferentially reaches the accessory salivary glands of the palate, lips and cheeks. We report in this work the observation of a 60 year-old patient who had discomfort with chewing and odynophagia whose paraclinical balance objectified a tissue process of the lateral posterior part of the left side of the gue including surgical exeresis and anabolic study objecting to a cystadenome.

Keywords: Salivary gland tumours (SGT), Cystadenoma, lips and cheeks, Odynophagia.

Copyright $\odot 2020$ The Author(s): This is an open-access article distributed under the terms of the Creative Commons Attribution 4.0 International License (CC BY-NC 4.0) which permits unrestricted use, distribution, and reproduction in any medium for non-commercial use provided the original author and source are credited.

\section{INTRODUCTION}

Cystadenoma is a rare epithelial tumour of the salivary glands WHO 2005. It preferentially reaches the accessory salivary glands of the palate, lips and cheeks. Parotids, however, remain a common location $(45 \%)$. The wide variability in the clinical expression of these tumours makes it difficult to establish an accurate diagnosis, hence the importance of histological analysis. There is a slight female predominance $[1,2]$. We report in this work the observation of a 60 -year-old patient who had discomfort with chewing and odynophagia whose paraclinical balance objectified a tissue process of the lateral posterior part of the left side of the gue including surgical exeresis and anabolic study objecting to a cystadenome.

\section{CASE REPORT}

The reported case is about a 60 -year-old man with no particular pathological history who has been presenting discomfort for a month when chewing ; with the installation of an odynophagia motivating his consultation in the emergency room, the clinical examination finds in endo oral a normal-looking healthy-looking lingual mucosa language with a lateral posture to the left, the rest of the clinical low examination of healthy language ,the clinical examination supplemented by a normal returned pan endoscopy, CT objectified a tissue process of spontaneously high density slightly enhanced after injection of contrast product developed at the left lateral posterior part of the tongue $2.7 \mathrm{~cm}$ wide and $4.5 \mathrm{~cm}$ in height this lesion came to contact with the mandibular corticale without sign of its invasion not exceeding the midline not exceeding the midline, without cervical adenopathy (Figure $1 \& 2$ ).

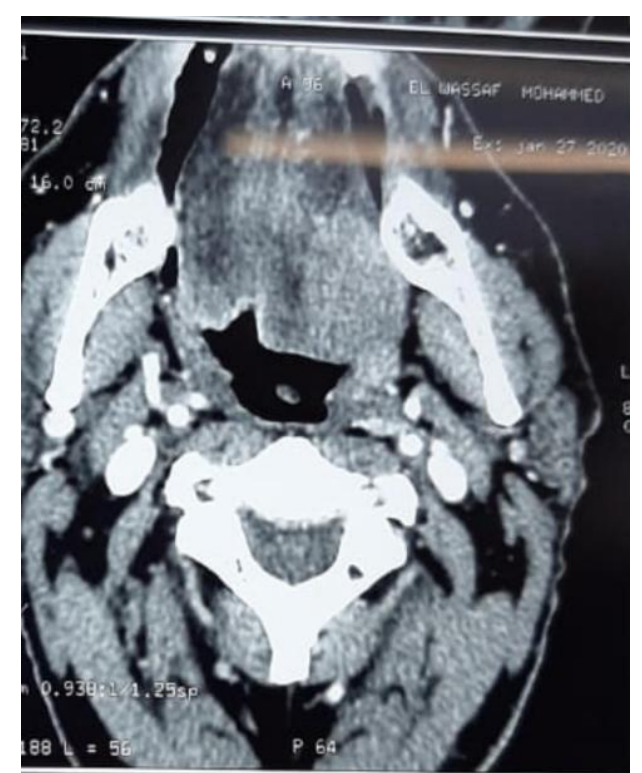

Fig-1: Image of the cervical scanner will mount the lingual lesion 


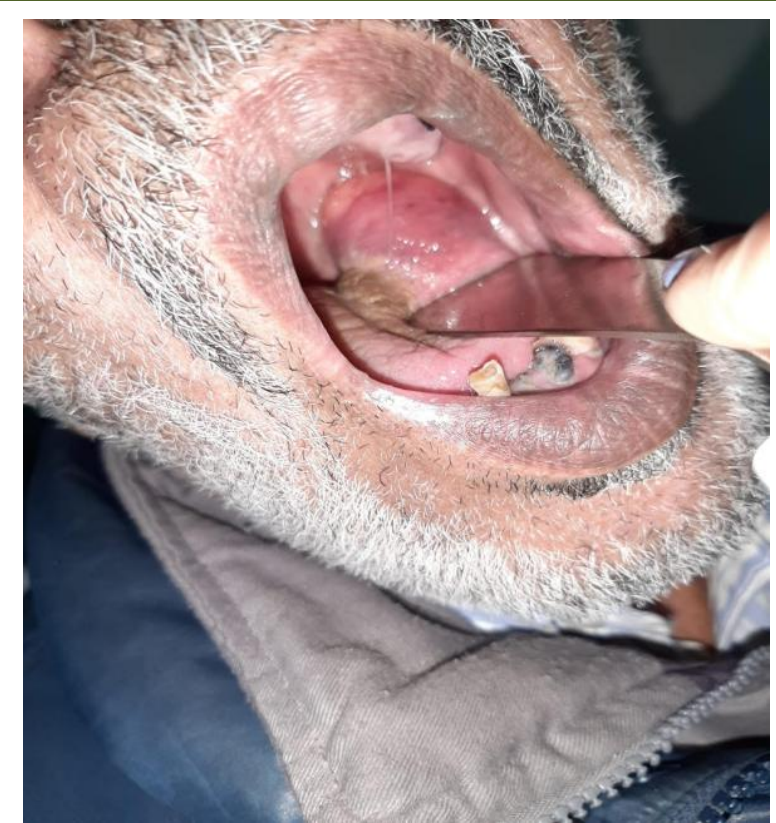

Fig-2: Picture showing the appearance of the lingual lesion

The patient underwent a single-block exeresis of the lesion, The incision of the lining reveals a yellow-colored cystic lesion, the contents of which is an opalin and viscous liquid.

The anatomopathological examination shows a formation largely consisting of juxtaposed cystic cavities, rounded or oval forms, scalloped, containing abundant eosinophilic material; some cavities have an epithelium with internal cells containing some mucus vacuoles, and external myoepithelial cells. There are also associated canal structures, scalloped, bordered by a double coating. Interstitial tissue is made up of physiological connective elements, dotted with mononucleous inflammatory cells and macrophages. The pathologist concludes that a cystadenoma developed on an accessory salivary gland.

\section{DISCUSSION}

Salivary gland tumours(SGT) represent an important chapter of facial cervico pathology. Salivary gland tumours are rare and very varied. They account for $3 \%$ of all tumours in the body and $6 \%$ of head and neck tumours [3, 4]. They are dominated morphologically by their lesionic polymorphism. This polymorphism is further enhanced, especially clinically, by the diversity of possible seats.

There is no known risk factor. The majority of these tumors are permanently curable; however, the possibility of histological malignancy should never be ruled out.

The lack of data provided by the further examinations of surgical exploration is the essential time by the anatomopathological examination that it authorizes. Benign tumours make up $60 \%$ of salivary gland tumours, of which more than $50 \%$ are pleomorphic adenomas, especially in the main salivary glands [3,5]. But the distribution is different in both gland groups: the tumors of the main salivary glands (GSPs) are three times out of four benign, while $60 \%$ of the tumors of the accessory salivary glands are malignant.

Accessory or minor salivary glands: scattered in the mucous membranes of the oral cavity: palate, lingual, jugal and lip.

Cystatenoma is a tumor that accounts for $4.1 \%$ of benign salivary gland tumors so it is a benign tumor. It is more common in women than in men with a peak between the age of 60 and 80 . This pathology is located in $64 \%$ of the main salivary glands mainly in the parotid gland, then the submandibular and sublinguals.

The salivary glands are also affected in the lips of the palate, the jugal mucosa and the diaper. Other sites can be reached the larynx, nasopharynx, nasal cavities, kidneys, tear glands and ovaries. Some author calls it "Wharton tumors without lymphoid stroma" given the great resemblance. Clinically this tumor manifests itself as a small, well-defined, slightly decompressible asymptomatic round nodule.

This nodule takes on varying sizes depending on its location, it takes the size of $1 \mathrm{~cm}$ in the accessory salivary glands and can reach the size of $06 \mathrm{~cm}$ in the parotid. There are no changes in the oral mucosa in the area, either colour or appearance.

Its growth is slow and sometimes presents sensitivities depending on the patient. Chronic inflammation is found in $55 \%$ of cases, no adenopathies or any infiltration found.

Its configuration appears variable, two types coexist, papillary cystadenoma exists in the form of my cystic or polycystic containing multiple epithelial projections surrounded by oocytes, and second type cystadenoma which manifests itself in multiple cysts surrounded by cells of the epithelial lining.

The size of the cysts remains very irregular between them, the cysts contain epithelial cells and mucous protein fluid material eosinophilic material and body.

The differential diagnosis remains the mucocele and tumor of the Wharton given the great resemblance.

Treatment relies on exeresis especially parotidectomy when it comes to parotidation location with facial nerve retention. Surgery usually appears sufficient as there is no local recurrence [7-11]. 


\section{CONCLUSiON}

Cystadenoma is a rare epithelial tumour of the salivary glands. Treatment is based on surgery which is generally sufficient but despite this it is necessary to remain vigilant given the risk of malignant transformation.

\section{REFERENCES}

1. Mathieu A, Laurence S, Gérard E, Pluot M, Lefèvre B, Hafian H. Cystadénome salivaire: à propos d'une tuméfaction jugale. 56ème Congrès de la SFMBCB. 2011:02015.

2. Sergheraert J, Grenier S, Mauprivez C, Lefevre B, Laurence S. Cystadénome papillaire d'une glande salivaire accessoire. A propos d'un cas. 66ème Congrès de la SFCO. 2020:02011.

3. Bonfils P. Tumeurs des glandes salivaires. Encycl. Méd. Chir.(Paris-France), Oto-RhinoLaryngologie. 2007 Jan:20-628.

4. van der Wal JE, Leverstein H, Snow GB, Kraaijenhagen HA, van der Waal I. Parotid gland tumors: histologic reevaluation and reclassification of 478 cases. Head \& Neck: Journal for the Sciences and Specialties of the Head and Neck. 1998 May;20(3):204-7.

5. da Cruz Perez DE, Pires FR, Alves FA, Almeida OP, Kowalski LP. Salivary gland tumors in children and adolescents: a clinicopathologic and immunohistochemical study of fifty-three cases. International journal of pediatric otorhinolaryngology. $2004 \mathrm{Jul}$ 1;68(7):895-902.

6. Siriman Ibrahima MT. Tumeurs Des Glandes Salivaires Dans Le Service De Stomatologie Et De Chirurgie Maxillo-Faciale Du Centre Hospitalier Universitaire D'odontostomatologie (Chu-Os) De Bamako. 2013. Thèse de la Faculté de Médecine, et d'Odonto-stomatologie.

7. Barnes I. Surgical pathology head \& neck .volume 1.4 ed. New YORK: Marcel DEKKER 2000.

8. Barnes. Pathologic \& genetics of head \& neck tumors. LYON: international agency for research on cancer; 2005.

9. Gallego L, Junquera Gutiérrez LM, Fresno Forcelledo MF, Vicente Rodríguez JC. Papillary cystadenoma and cystadenocarcinoma of salivary glands: two unusual entities. Med Oral Pat Oral Cir Bucal. 2008; 13(7):460.

10. Gnepp DR. Diagnostic surgical pathology of head \& neck. Pheladelphie: Saunders, 2000.

11. Lim CS, Ngu I, Collins AP, McKellar GM. Papillary cystadenoma of a minor salivary gland: report of a case involving cytological analysis and review of the literature. Oral Surgery, Oral Medicine, Oral Pathology, Oral Radiology, and Endodontology. 2008 Jan 1;105(1):e28-33. 